\title{
MOET'S THREE PILOT ENGLISH LANGUAGE COMMUNICATIONAL CURRICULA FOR SCHOOLS IN VIETNAM: RATIONALE, DESIGN AND IMPLEMENTATION
}

\author{
Hoang Van Van* \\ Center of Foreign Language Education Research, Linguistics and International Studies, \\ VNU University of Languages and International Studies, Pham Van Dong, Cau Giay, Hanoi, Vietnam
}

Received 19 January 2018

Revised 26 March 2018; Accepted 29 March 2018

\begin{abstract}
In this paper ${ }^{(1)}$, Ministry of Education and Training (MoET)'s three pilot English language communicational curricula for schools in Vietnam will be discussed. In doing so, we will organize the article into four main parts. Part 1 states the reason for the choice of the topic. Part 2 examines the rationale for the development of MoET's three pilot English language communicational curricula for schools in Vietnam. Part 3 is the focus of the article. In this part, we will first provide an overview of Common European Framework of Reference for Languages: Teaching, Teaching, Assessment (CEFR) and Threshold Level English - two important studies that have laid theoretical grounds for the development of the three pilot English language communicational curricula for schools in Vietnam. Then we will describe in some detail the design of MoET's three pilot English language communicational curricula for schools in Vietnam and discuss their trial implementation, highlighting the achievements and the problems encountered during the implementation process. In the final section, after summarizing the contents discussed, we will recommend the integration of MoET's three pilot English language communicational curricula for schools in Vietnam into a single text presumably called English Curriculum for Schools in Vietnam and propose some recommendations on what should be done to overcome the problems before putting the Curriculum into use throughout Vietnam.
\end{abstract}

Keywords: MoET's three pilot English language communicational curricula, CEFR, Threshold Level English, National Foreign Languages 2020 Project (NFL 2020 Project)

\section{Introduction}

The literature on the teaching of the kind(s) of English other than "English as the First Language or as the Mother Tongue" is replete with the topic of this conference. At the societal level, it is obvious that the range of possible contexts for the teaching of English varies from country to country.

\footnotetext{
* Tel.: 84-946296999

Email: vanhv.sdh@gmail.com

${ }^{1}$ This paper was presented at the plenary session of the Third International VietTESOL Conference entitled English Language Education in Diverse Contexts held at Thai Nguyen University on 7-8 December, 2017.
}

This is reflected in the terms that have been proposed to distinguish different settings and circumstances for the use of English, such as English as a Second Languge, English as a Foreign Language, or English as an International Language. Looking a bit further down at the methodological and individual levels, it seems to me that in moving from the traditional approaches to second and foreign language teaching to the approach which has been commonly referred to as Communicative Language Teaching (CLT), we have merely rediscovered what 
the good teacher in class knew all along, that in any context one does not learn another language until one actually uses it to satisfy one's genuine need to talk about something important to oneself and to others. For these reasons, in this paper I will not intend to talk about the contexts for the teaching of English in countries of the world; neither will I intend to talk in a general manner about the methods and techniques students and teachers employ to learn and teach a second and a foreign language in the classroom. What I will do is to look specifically at an issue which has been attracting much attention from education administrators, foreign language methodologists, foreign language teachers and pupils, and parents in Vietnam: MoET's three pilot English language communicational curricula for schools in Vietnam. As a way of start, I will first present the introduction to the study. Then I will discuss the rationale for the development of MoET's three pilot English language communicational curricula. This is followed by Section 3 - the focus of the paper - where I will first provide an overview of Council Europe's Common European Framework of Reference for Languages: Learning, Teaching, Assessment (2001) and Threshold Level of English (1980) - the two important studies that have laid theoretical foundations for the development of MoET's three pilot English language communicational curricula. Then I will describe the design of MoET's three pilot English language communicational curricula and discuss their pilot implementation in schools in Vietnam, paying particular attention to their strengths and the problems experienced during the implementation process. In the final section, having summarized what has been discussed, I will recommend some suggestions on what should be done to overcome the problems before putting MoET's three pilot English language communicational curricula for schools in Vietnam into use on a large scale.

\section{Why three new English language communicational curricula for schools in Vietnam?}

Because of many misunderstandings that have occurred recently about the current situation of the learning and teaching of English in Vietnamese schools, three points should be made clear before I address the question raised in the heading. First, although MoET's three new English language curricula for schools in Vietnam have been implemented for 7 years (since late 2010), they are in their trial stage. The English language curriculum that is in use in all lower and upper secondary schools (from Grade 6 to Grade 12) throughout Vietnam is the sevenyear programme. Secondly, although English is now being taught in many primary schools in Vietnam, it is an optional subject; any school may teach one, two, three, four or even more than four hours a week depending on its available resources. And thirdly, although several teaching materials (both local and non-local) are being used in Vietnamese primary schools, except for MoET NFL 2020 Project's primary English textbooks (Tiếng Anh 3, Tiếng Anh 4, and Tiếng Anh 5), they have not yet been evaluated and approved by MoET.

Now turing to the question, "Why three new English language communicational curricula for schools in Vietnam?", I would like to reveal this story: "In 2012, when we MoET NFL 2020 Project textbook development team in collaboration with our MacMillan Education and Pearson Education textbook writing colleagues were working on the new ten-year English textbook series, MoET Department for Secondary Education gathered experts and experienced teachers to come to 'reduce the workload' of the 
textbooks of the seven-year programme" with the explanation that the contents of the textbooks were overloaded. On hearing this episode, one may wonder why three new English language curricula for schools in Vietnam are needed while the contents of the current one are thought to be overloaded, and a question one may raise is "Are there reasons for the change?" The short answer to this question is surely "Yes", and they can be explicated as follows:

Firstly, over the past few decades experimentation and psychological researches into foreign language learning have indicated that the earlier a foreign language is introduced in school programmes, the greater the likelihood the success in learning (see Lenneberg, 1967; Stern, 1967; Rivers, 1970; Broughton et al, 1978; Eurydice, 2005; Lightbown \& Spada, 2008; Nikolov, 2009; see also Viện khoa học Giáo dục Việt Nam, 2008). This view has attracted strong support from the Vietnamese Government, Vietnamese educational thinkers and administrators.

Secondly, nowadays Vietnamese parents want their children to learn English earlier than the current seven-year programme could offer. In the hope that their children will have the right kind of start for a new kind of society, many parents, particularly the young ones in urban and affluent areas send their children to private foreign language centers to learn English even when they are pre-schoolers.

Thirdly, the teaching of foreign languages, particularly English, in the primary school has been flourishing the world over. In many countries where English is taught as a foreign language such as Luxembourg, Malta, the Netherland, Norway, China, Thailand, South Korea, and many others, English is introduced in the primary school from Grade 3 and even earlier (see Nunan, 2003; Eurydice, 2005; Lee, 2005; Lam, 2005; Rubdy and Tupas, 2009; Liu, 2010; Darus, 2010; Kwon, 2010; Chan et al, 2011; Pew Research Center, 2015; Hoang Van Van, 2010, 2017; and many others).

Finally and most importantly, the reason that accounts for the change to the three English language curricula is rapid internationalization and globalization. It is clear that in a world in which internationalization and globalization are becoming an inevitable trend, the need for high-skilled and highly qualified people who can communicate effectively in English has become an urgent requirement for Vietnam. This has made it difficult for the country to sustain the current standards of teaching, learning and use of English. Increasingly, decision-making bodies were becoming aware that without a radical change in the English curriculum, Vietnamese learners' standards of performance in English would be left behind. Recognizing the importance of foreign languages in the context of globalization and internationalization, on $30^{\text {th }}$ September, 2008, the Prime Minister of the Socialist Republic of Vietnam signed Decision $\mathrm{N}^{0} 1400 / \mathrm{Q}$-TTg to promulgate the National Project entitled Teaching and Learning Foreign Languages in the National Education System, Period 2008-2020. In this special document, a very important part is devoted to the learning and teaching of English in Vietnamese schools which states: "To implement a ten-year foreign language programme, starting from Grade 3 with the compulsory foreign language" (Page 1), and "To organize the design of the ten-year curricula for the foreign languages being taught in schools in Vietnam, from Grade 3 to Grade 12, and the compilation of textbooks and other learning and teaching materials suitable to the requirements for each level and each grade" (Page 2). ${ }^{(2)}$ In the rest of the paper, I shall be concerned exclusively with

2 Unless otherwise stated, I am responsible for the Vietnamese-English translation throughout this paper. 
the design and implementation of MoET's three pilot English language communicational curricula for schools in Vietnam.

\section{MoET's three pilot English language communicational curricula for schools in Vietnam}

\subsection{Theoretical foundations}

The last three decades of the second half of the $20^{\text {th }}$ century saw a number of new and significant developments in Western Europe, both theoretical and pedagogical, on foreign language learning and teaching. One such significant development was that pioneered by the Council of Europe group. This small committee of language teaching experts was set up in 1971 with the purpose of examining the feasibility of developing a unit/credit system for foreign language learning by adults as proposed by a Council of Europe symposium held in the same year. The group's work has resulted in a number of fundamental studies and practical applications, two of which are Common European Framework of Reference for Languages: Learning, Teaching, Assessment (CEFR) and Threshold Level English. As these studies have been most widely used and have had direct and indirect influences on the design of MoET's three pilot English language communicational curricula for schools in Vietnam, they will be reviewed briefly below.

CEFR, ever since its inception, has had profound impacts on language teaching, learning, and assessment not only in Europe but also in other parts of the world. In its 2001 version, CEFR consists of 9 chapters and four appendices. Chapter 1 places the framework in the political and educational context. More specifically, it presents in some detail what CEFR is, what are the aims and objectives of Council of Europe's language policy, why the framework is needed, for what uses it is intended and the criteria the framework must meet. Chapter 2 presents the approach adopted in CEFR which consists of four main sections: Section 1 presents the action-oriented approach; Section 2 is concerned with common reference levels of language proficiency; Section 3 looks at language learning and teaching in the action-oriented approach; and Section 4 discusses some issues of language assessment. Chapter 3 is concerned with global scale of common reference levels consisting of three broad levels - A, B and C and their six branching levels: $\mathrm{A}-\mathrm{A} 1$ and $\mathrm{A} 2, \mathrm{~B}-\mathrm{B} 1$ and $\mathrm{B} 2$, and $\mathrm{C}-\mathrm{C} 1$ and $\mathrm{C} 2$, presenting each of them in a single holistic paragraph, and providing illustrative descriptors referring to the three metacategories of communicative activities, strategies, and communicative language competences. One interesting point that should be noted here is that the framework suggests a scheme of flexibility in a branching level. This is a very important suggestion for curriculum designers (and textbook writers as well) because without a flexible branching scheme, it would be difficult for them to cut a common set of levels "into practical local levels at different points by different users to suit local needs and yet still relate back to a common system" (Council of Europe, 2001: 32) and to make further subdivisions without losing the reference to the main objective being referred to. The three broad reference levels, their six branching levels, and their more delicate levels can be represented in Figure 1 below.

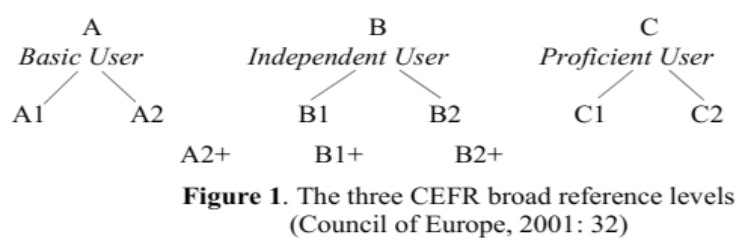

Chapter 4 explores issues such as context of language use and the language learner (including domains, situations, conditions and constraints, the learner's and the interlocutor's mental context), communication themes and topics, communicative tasks and 
purposes, communicative language activities and strategies, communicative language processes, texts. Chapter 5 discusses the user/learner's competences at each specified level of proficiency which includes general competences: declarative knowledge, skills and know-how, existential competence and ability to learn, and communicative language competences: linguistic competences, sociolinguistic competences, and pragmatic competences. Chapter 6 presents language learning and teaching which includes what the learner has to learn or acquire the processes of language learning, and some methodological options for modern language learning and teaching. Chapter 7 discusses learning tasks and their role in language teaching which includes task description, task performance, and task difficulties. Chapter 8 explores linguistic diversification and the curriculum which includes options for curricular design, towards curriculum scenarios, some examples of differentiated curriculum scenarios, with particular attention being paid to the multidimensionality and modularity in developing a sound basis for linguistic diversification in the curriculum and in assessment. And Chapter 9 describes the assessment of the proficiency of the language user. It presents in detail the framework as resource for assessment which consists of a number of issues such as specification of the content of tests and examinations, criteria for attainment of the learning objective, description of the levels of proficiency of tests and examinations to aid comparison, and types of assessment.

Each of the four appendices is concerned with one aspect of proficiency descriptors. Appendix A - Developing Proficiency Descriptors - presents technical aspects of describing levels of language attainment which consists of formulating criteria for descriptors and listing methodologies for scale development. Appendix B - The Illustrative Scales of Descriptors - is about a description of the Swiss project which developed the illustrative descriptors for CEF. Appendix C - The DIALANG Scales - contains a description of the DIALANG language assessment system which is an application for diagnostic purposes of CEF, focusing on the self-assessment statements used in the system and the calibration study carried out on them as part of the development of the system. And Appendix D - The ALTE (Association of Language Testers in Europe) 'Can Do' Statements - focuses on describing the nature of the 'Can Do' statements, the ways the statements are developed, related to ALTE examinations and anchored to the CEF.

As mentioned, CEFR was developed in Western Europe and was targeted mainly at adult foreign language instruction. Van Ek and Alexander, two of the leading members of the Council of Europe group, have adapted this framework for foreign language learning and teaching in schools in their best known publication entitled Threshold Level English (1975/1980) and in van Ek's own publication entitled The Threshold Level for Modern Language Learning in Schools (1977) (hereafter referred to as "the van Ek \& Alexander syllabus model"). Many of the insights from these works have been employed for foreign language syllabus design in other contexts (cf. Chamot, 1987; Finch, 2009; Broek, S. I. van den Ende, 2013; Bučar, et al, 2014; and many others). This is because they are a typical example of the emphasis and mood of the new "communicative movement" in that, to the authors, meaning, function and use of language are more important than its form. They are an attempt at defining the basic minimum needs of foreign language learners in order to be able to communicate nonprofessionally with foreign language speakers in everyday situations on topics of general 
interests. The basic characteristic of the van Ek \& Alexander syllabus model is that it tries to specify foreign language activity as skill rather than knowledge. It focuses on what the learner will have to be able to do in the foreign language and determines in the second place what language-forms (words, structures, etc.) the learner will have to be able to handle (van Ek \& Alexander, 1975/1980; van Ek, 1977; see also van Ek, 1998). This shift in emphasis was paralleled by a similar trend in the domain of linguistics itself, where functional linguists and sociolinguists like Halliday (1973, 1978, 1991, 1998) and Hymes (1972 and elsewhere) had for some time argued for greater attention to be paid to the communicational function of language rather than its structural form - the vigorous emphasis by earlier structural linguists like Bloomfield, Fries, and Chomsky and his followers. "There are rules of use without which rules of grammar would be useless" (Hymes, 1972: 278). And more importantly,

In communication, speakers and hearers (and writers and readers) are most often engaged in the work of sharing meaning which are both dependent on the conventions of interpersonal behaviour and created by such behaviour. Similarly, the ideas or concepts which are communicated about contain different potential meanings and such potential meanings are expressed through and derived from the formal system of text during the process of communication. To understand the conventions which underlie communication, therefore, we not only have to understand a system of ideas or concepts and a system of interpersonal behaviour, we have to understand how these ideas and this interpersonal behaviour can be realized in language - in connected texts. Mastering this unity of ideational, interpersonal and textual knowledge allows us to participate in a creative meaning-making process and to express or interpret the potential meanings within spoken or written texts.
(Breen \& Candlin, 1980: 90)

3.2. The design of MoET's three pilot English language communicational curricula for schools in Vietnam

\subsubsection{Introductory notes}

It should be noted here that up till now nothing has been done to move from the centralized English language curriculum prepared and issued by MoET. Therefore, all schools in Vietnam, termed either public or private, come under the administrative umbrella of MoET. As such schools are strongly influenced by the policies and guidelines that stem from the Ministry. These policies and guidelines touch on all aspects of school administration, and school learning and teaching. Among the documents prepared and issued by the Ministry are the three pilot English language curricula for schools in Vietnam which are prescribed for all schools.

To design the three pilot English language curricula, a team was appointed by MoET in mid 2010 with the Vietnam National Institute for Educational Sciences (VNIES) working as the organizing institution. The team consisted of English curriculum specialists, native speakers of English language specialists from the British Council, university and college lecturers, evaluation specialists and experienced school teachers. One of the first tasks the team had to set for itself was to take a closer look at the target learners and to reidentify their needs to learn English in the professional and social world relevant to the national and international situations in the first decades of the $21^{\text {st }}$ century. A consensus was reached, and due to time and human resource constraints, MoET decided to break down the ten-year English programme into three separate curricula (hence the term "MoET's three Pilot English Language Communicational Curricula for Schools in Vietnam"), one for primary level, one for lower secondary level 
and one for upper secondary level. After two years' work, the team succeeded in producing three English language curricula for schools in Vietnam referred to respectively in MoET's three Decisions as (1) Chuoong trinh tiếng Anh thi điểm tiểu học (Pilot English Language Curriculum for Primary Schools in Vietnam) (2010), (2) Chuoong trình giáo dục phổ thông môn tiếng Anh thi điểm cấp trung hoc co sỏ (Pilot English Language Curriculum for Lower Secondary Schools in Vietnam) (2012a), and (3) Chuoong trình giáo dục phổ thông môn tiếng Anh thi điểm cấp trung hoc phổ thông (Pilot English Language Curriculum for Upper Secondary Schools in Vietnam) (2012b).

MoET's three pilot English language curricula for schools in Vietnam are communication-based, drawing on insights from several English language school curricula of countries in the region and in the world such as Singapore, Malaysia, China, Thailand, South Korea, and Japan. In particular, they draw heavily on insights from the CEFR model developed by Council of Europe (2001) and the van Ek \& Alexander syllabus model. They all are structured into two main parts. Part 1 presents the curriculum framework and Part 2 provides a sample syllabus outline.

\subsubsection{The curriculum framework}

The curriculum framework contains the following sections: (1) principles of curriculum design, (2) curriculum objectives, (3) curriculum contents, (4) teaching methodology, (5) assessment, and (6) conditions for successful curriculum implementation.

(1) Principles of curriculum design. Although there are differences in the number of principles of curriculum design in each of the three curricula (6 in the primary curriculum, 10 in the lower secondary curriculum, and 9 in the upper secondary curriculum), they all lay emphasis on seeing as principle the learning needs of the students, the development of students' positive attitudes towards English, the contribution of English learning to the overall educational development of the students, the development of communicative competences through integrated practice of four communicative macroskills of listening, speaking, reading and writing, the delivery through coherent themes and topics which are meaningful and relevant to the students' worlds, the learning-centred teaching approach, the coherent integration and articulation between the three curricula, the flexibility to reflect local concerns, needs and capacities across a wide range of contexts in Vietnam, and the alignment of the learning outcomes with CEFR Level A1 in the primary curriculum, CEFR Level A2 in the lower secondary curriculum, and CEFR Level B1 in the upper secondary curriculum.

(2) Curriculum objectives. This section includes two subsections: general objectives and specific objectives. The general objectives section states the general aims of the three curricula in terms of global scale related to what students will have reached by the end of each level. The global scale statements are taken from the first three levels of CEFR's "Common Reference Levels: global scale". Accordingly, by the end of the primary level, students will have reached the equivalent of CEFR Level A1; by the end of the lower secondary level, students will have reached the equivalent of CEFR Level A2, and by the end of the upper secondary level, students will have reached the equivalent of CEFR Level B1. The global scale statements of these levels are given in Table 1. 
Table 1. Global scale statements of CEFR Levels A1, A2 and B1

\begin{tabular}{|c|l|}
\hline B1 & $\begin{array}{l}\text { Can understand the main points of clear standard input on familiar matters } \\
\text { regularly encountered in work, school, leisure, etc. Can deal with most } \\
\text { situations likely to arise whilst travelling in an area where the language is } \\
\text { spoken. Can produce simple connected text on topics which are familiar or of } \\
\text { personal interest. Can describe experiences and events, dreams, hopes and } \\
\text { ambitions and briefly give reasons and explanations for opinions and plans. }\end{array}$ \\
\hline A2 & $\begin{array}{l}\text { Can understand sentences and frequently used expressions related to areas of } \\
\text { most immediate relevance (e.g. very basic personal and family information, } \\
\text { shopping, local geography, employment). Can communicate in simple and } \\
\text { routine tasks requiring a simple and direct exchange of information on } \\
\text { familiar and routine matters. Can describe in simple terms aspects of his/her } \\
\text { background, immediate environment and matters in areas of immediate } \\
\text { need. }\end{array}$ \\
\hline A1 \\
$\begin{array}{l}\text { Can understand and use familiar everyday expressions and very basic phrases } \\
\text { aimed at the satisfaction of needs of a concrete type. Can introduce } \\
\text { him/herself and others and can ask and answer questions about personal } \\
\text { details such as where he/she lives, people he/she knows and things he/she } \\
\text { has. Can interact in a simple way provided the other person talks slowly and } \\
\text { clearly and is prepared to help. }\end{array}$ \\
\hline
\end{tabular}

(Council of Europe, 2001: 24)

The specific objectives section is related to what students can do in terms of their knowledge and ability to use English, their change in attitude towards English, and their learning strategies on completing each level. It is also concerned what students can do in terms of four communicative areas of listening, speaking, reading and writing at three levels of education which cover all ten grades.

In any foreign language programme, especially in one that is comprised of a number of levels like MoET's three pilot English language curricula project, there is danger that the learning contents could be broken, discontinued, fragmented, incoherent, and unsystematic. In order to overcome these problems and to systematically move students along the path towards the level of proficiency required for upper secondary school leavers, the overall perspective of the development path from Grade 3 through to Grade 12 needs to be specified. Drawing on the insights from CEFR's flexible branching scheme, MoET's three pilot English curricula for schools in Vietnam define levels of English proficiency at 3 level points along the path from Zero to CEFR Level B1. Then based on the structure of the Vietnamese general education system (which is comprised of 12 grades), each level point is broken down into more delicate levels for further definitions. The definitions provide some detailed descriptions of language knowledge and language skills to allow the curriculum designers (and textbook writers) to perceive how each grade and each level fit into the total pattern of proficiency development. Thus in Moet's three pilot English language curricula, three sets of specifications are developed spanning the three levels from Zero to Level A1 which includes Level A1-1 for Grade 3, Level A1-2 for Grade 4 and Level A1-3 for Grade 5, to Level A2 which includes Level A2-1 for Grade 6, Level A2-2 for Grade 7, Level A2-3 for Grade 8, and Level A2-4 for Grade 9, and to Level B1 which includes Level B1-1 for Grade 10, Level B1-2 for Grade 11, and Level B1-3 for Grade 12. Below is an extract taken from the Pilot English Language Curriculum for Lower Secondary Schools in Vietnam describing the specific objectives students must achieve on finishing Grade 6. 
Table 2. Specific objectives of Grade 6

When finishing Grade 6, pupils can:

\begin{tabular}{|c|c|}
\hline Listening & $\begin{array}{l}\text { - Recognize and repeat sounds, stresses, intonations and rhythms in different short and simple sentences. } \\
\text { - Understand short and simple instructions that are used in learning activities in the classroom. } \\
\text { - Understand the main ideas and details of simple dialogues and monologues of } 60 \text {-word length about } \\
\text { the topics suggested in the curriculum such as family, school, friends, festivals, tourist attractions, } \\
\text { famous people, television, sports... } \\
\text { - Understand the main ideas of information exchanges between friends of the same age about the topics } \\
\text { suggested in the syllabus. }\end{array}$ \\
\hline Speaking & $\begin{array}{l}\text { - Pronounce correctly sounds, stresses, rhythms and intonations in short and simple sentences. } \\
\text { - Produce short and simple instructions that are used in learning activities in the classroom. } \\
\text { - Ask and give short answers about the topics in the curriculum such as family, school, friends, } \\
\text { festivals, tourist attractions, famous people, television, sports... } \\
\text { - Produce simple and connected sentences with suggestions about familiar topics. }\end{array}$ \\
\hline Reading & $\begin{array}{l}\text { - Understand the main ideas and details of simple dialogues and monologues of } 80 \text {-word length about } \\
\text { the topics suggested in the syllabus such as family, school, friends, festivals, tourist attractions, } \\
\text { famous people, television, sports... } \\
\text { - Understand the main ideas of personal letters, notices, short and simple paragraphs about familiar } \\
\text { topics (possibly with some new words and structures). }\end{array}$ \\
\hline Writing & $\begin{array}{l}\text { - Write short and simple instructions of about } 50 \text {-word length about the topics suggested in the } \\
\text { curriculum such as family, school, friends, festivals, tourist attractions, famous people, television, } \\
\text { sports... } \\
\text { - Write short and simple letters, postcards, messages or personal notes related to daily communication } \\
\text { needs,... about the topics that are suggested in the syllabus. }\end{array}$ \\
\hline
\end{tabular}

(Bộ Giáo dục và Đào tạo [MoET], 2012a: 7)

(3) Curriculum contents (Syllabus). This section provides the total time frame allocated for the three pilot English language curricula whose contents include themes, topics, communicative competences, and linguistic knowledge. These are designed to be delivered in 1155 periods of which 420 (35-minute) periods are for the primary level, 420 (45-minute) periods are for the lower secondary level, and 315 (45-minute) periods are for the upper secondary level.

The theoretical foundation on which the design of the three pilot English language curricula is based can be found in the CEFR (2001). The theoretical foundation on which the design of the three syllabuses, for the most part, can be found in the notional/functional syllabus developed in Threshold Level English by van Ek \& Alexander (1975/1980) and in The Threshold Level for Modern Language Learning in Schools by van Ek (1977). The notional/functional syllabus is communicative in that it represents a radical departure from grammatical/structural approach to foreign language syllabus design. It looks at foreign language from a pragmatic rather than a descriptive point of view. It sees foreign language as a skill that allows one to get things done. It takes as departure general notions which are expressed in spatial and temporal and specific notions such as personal identification, house and home, relations with other people, travel, education, and so forth. The things that can be done are described in functions such as greeting, leave-taking, complementing, expressing attitudes, etc. These functions are stated in terms of skills (listening, speaking, reading and writing) and are realized in linguistic structures (phonetics, vocabulary and grammar).

As mentioned above, the notional/ functional syllabus was initially developed for adult foreign language learning and teaching. Later van Ek (1977) and van Ek 
and Alexander (1975/1980) have adapted it for foreign language learning and teaching in schools, so it can be applied to designing foreign language syllabus in other contexts. Drawing on insights from CEFR's notional/ functional syllabus, MoET's three pilot English language syllabuses for schools in Vietnam are designed into 4 components:

(1) Themes $(\approx$ general notions in the van Ek \& Alexander syllabus model), broken down into $(2)$ topics $(\approx$ specific notions in the van Ek \& Alexander syllabus model), (3) communicative competences $(\approx$ functions in the van Ek \& Alexander syllabus model), and (4) linguistic knowledge/language items (pronunciation, vocabulary, and grammar).

One of the key elements in MoET's three pilot English language curricula for schools in Vietnam is the development of students' capacity to take increasing responsibility for their own learning as they progress from the primary through to the lower secondary and then the upper secondary level. To accomplish this process, students must learn to use effective language learning strategies. All the three pilot English language curricula recommend that "learning how to learn" should be included in textbooks and other teaching materials and should be incorporated by teachers in their lessons. To guide textbook writers and teachers to translate this recommendation into reality, a list of language learning strategies is provided in each of the three curricula. (For detail, see Bộ Giáo dục \& Đào tạo [MoET], 2010a, 2012a, 2012b).

(4) Teaching methodology. MoET's three pilot English language curricula strongly recommend that teaching English in schools in Vietnam should be based on a locally appropriate application of Communicative Language Teaching (CLT) and an understanding of psychological characteristics of students who are moving from childhood to adolescence. The ultimate goal of learning is to cultivate in students the ability to understand and to communicate in English in a variety of real-life contexts. To achieve this goal, English teaching in schools in Vietnam should focus on a learningcentred approach in which teachers must see students as active participants in the language learning process and their own role as an organizer and facilitator of students' learning. Wherever possible, teachers should make use of electronic teaching and learning resources to foster students' interest in the subject and to help them achieve the objectives of the curricula. It is suggested that the three pilot English language curricula be implemented in the classroom through tasks and activities for all four skills which require students to engage in meaningful interaction using the language.

(5) Assessment. Students' achievement in English shall be based on evidence of their use of communicative competences gained during the learning process. The three pilot English language curricula require that assessment conform to the teaching and learning approaches used in the classroom and that throughout the school year assessment should be primarily formative, enabling both students and teachers to see progress towards achieving the curriculum objectives for the year. At designated points throughout the school year, such as at the end of each term and at the end of the year, summative assessment will also be required to gauge students' achievement of the objectives. To assess students' communicative competences, it is recommended that formats of assessment be diverse in nature and include assessment of speaking and listening as interactive skills, as well as reading and writing skills.

(6) Conditions for successful curriculum implementation. For the three curricula to be successfully implemented in schools, the following conditions are proposed:

1. Adequate teaching time shall be 
available. The three curricula are designed to be delivered in a total of 1155 periods, 420 periods for primary level, 420 periods for lower secondary level and 315 periods for upper secondary level.

2. Students finishing a grade should have achieved the required branching proficiency level. Accordingly, Grade 3 students should have achieved a level equivalent to CEFR A1-1, Grade 4 students - CEFR A1-2, Grade 5 students - CEFR A1-3, Grade 6 students - CEFR A2-1, Grade 7 students - CEFR A22, Grade 8 students - CEFR A.2-3, Grade 9 students - CEFR A.2-4, Grade 10 students - CEFR B1-1, Grade 11 students - CEFR B1-2, and Grade 12 students - CEFR B1-3.

3. There shall be a sufficient number of teachers with qualification at college or university level and with an English qualification equivalent to CEFR Level B2 for primary and lower secondary teachers and Level $\mathrm{C} 1$ for upper secondary teachers.

4. Teachers should be adequately trained to teach these curricula in the manner specified.

5. The number of students per class should not exceed the number prescribed by MoET.

6. Besides MoET's textbooks (student's books, teacher's guides, and workbooks), other material resources which have been assessed by a competent authority may be used.

7. A variety of audio-visual and electronic resources should be made available to support learning and teaching.

8. School managers should be given an opportunity to participate in in-service training for these curricula so that they are able to support teachers in their schools as they implement the new curricula.

9. Textbook writing teams should receive appropriate training to ensure that new textbooks are designed to meet the specifications and requirements of the new curricula.

\subsubsection{The sample outline syllabus}

A syllabus is usually a specification of what is considered to be the basic units of learning in the language. "Syllabus design does not take place in a vacuum. It is one stage within a broader sequence of curriculum development process" (Long \& Richards, 1987: 73). "The syllabus embodies that part of language which is to be taught, broken down into 'items' or otherwise processed for teaching purposes" (Strevens, 1985). Based on the insights from the Curriculum contents section, The MoET English curriculum designers provide three sample outline English syllabuses for schools in Vietnam. They recognise 12 themes (accompanied by the reasons for the choice), 4 for each level of education, as follows: primary level: $M e$ and My Friends, Me and My School, Me and My Family, Me and the World Around; lower secondary level: Our Communities, Our Heritage, Our World, Visions of the Future; and upper secondary level: Our Lives, Our Society, Our Environment, Our Future. These themes are broken down into around 150 topics to cover the whole school programme of 1155 teaching periods of which 420 periods are for the primary level, 420 periods are for the lower secondary level, and 315 periods are for the upper secondary level. These topics are followed by a suggested inventory of specific language functions (communicative competences) stated in terms of four communicative skills of listening, speaking, reading, and writing, and a suggested inventory of linguistic knowledge consisting of phonic/phonological, lexical and grammatical items. These socio-cultural and linguistic resources enable students to develop their communicative competences in the selected themes and topics. Cultural 
knowledge is a compulsory component in the three syllabuses; it is stated in the three curricula and is realized in textbooks and teacher materials. Below is a segment representing a sample outline syllabus of the primary level.
Education counterparts. The development of the textbook series was based on the guidelines of MoET's three pilot English language curricula and, in particular, on the contents suggested in the three syllabuses. Like the textbooks of the current seven-

Table 3. A segment of a sample outline of the primary English syllabus

1. Lớp 3

4 tiết/tuần $\times 35$ tuần $=140$ tiết

\begin{tabular}{|c|c|c|c|}
\hline THEMES & TOPICS & COMMUNICATIVE COMPETENCES & LINGUISTIC KNOWLEDGE \\
\hline $\begin{array}{l}\text { Me and My } \\
\text { Friends }\end{array}$ & $\begin{array}{l}\text { Meetings } \\
\text { Myself } \\
\text { Thanking } \\
\text { Our names } \\
\text { My Friends }\end{array}$ & $\begin{array}{l}\text { Greeting } \\
\text { Saying goodbye } \\
\text { Introducing oneself } \\
\text { Spelling someone's name } \\
\text { Greeting (Asking how someone is) } \\
\text { Thanking someone } \\
\text { Asking someone's name } \\
\text { Introducing others } \\
\text { Identifying someone } \\
\text { Greeting someone friendly }\end{array}$ & $\begin{array}{l}\text { Pronunciation: } \\
\text { Vowels } \\
\text { Diphthongs } \\
\text { Vocabulary: } \\
\text { Words to greet friends } \\
\text { The English alphabet } \\
\text { Words to indicate proper names } \\
\text { Words to name school facilities and objects } \\
\text { Words to describe school objects } \\
\text { Words to indicate actions } \\
\text { Words to name family members } \\
\text { Words to describe people } \\
\text { Words to name rooms in the house }\end{array}$ \\
\hline $\begin{array}{l}\text { Me and My } \\
\text { School }\end{array}$ & $\begin{array}{l}\text { My school } \\
\text { School objects } \\
\text { My classroom }\end{array}$ & $\begin{array}{l}\text { Introducing someone's school } \\
\text { Asking for the name of someone's school } \\
\text { Naming school facilities/objects } \\
\text { Describing school facilities/objects } \\
\text { Naming classroom objects }\end{array}$ & $\begin{array}{l}\text { Words to describe the weather } \\
\text { Words to name flowers, pets and toys } \\
\text { Words to describe flowers, pets and toys } \\
\text { Words to indicate colours } \\
\text { Cardinal numbers: } l-20 \\
\text { Ordinal numbers: } l^{s t}-20^{t h}\end{array}$ \\
\hline
\end{tabular}

(Source: Bộ Giáo dục và Đào tạo [MoET], 2010)

\subsection{Implementation of MoET's three pilot} English language communicational curricula for schools in Vietnam

\subsubsection{Textbook development}

To assist implementation of the three English language curricula, a ten-year English textbook development project was set up by MoET. This was a collaborative project between MoET Vietnam Education Publishing House (MoET VEPH) and MacMillan Education for the development of primary English textbooks and Pearson Education for the development of lower and upper secondary English textbooks. The project consisted of three Vietnamese textbook writing teams and their MacMillan Education and Pearson year programme, the new ten-year English textbook series is communication-based. It is comprised of 10 textbooks; each is designed for students to finish a grade and is structured around several units of lessons. A typical unit of lessons in the new textbook series begins with a topic, followed by language components (pronunciation, vocabulary and grammar) related to the topic, four macroskills of speaking, listening, reading and writing about the topic, communication and culture for further practice, and a project to help students to use real language in real contexts. The typical structure of a unit of lessons in the new ten-year textbook series, its component parts/headings and time allocated for each component part is provided in Table 4 . 
Table 4. Unit structure, component headings and time allocated for each component heading in the new textbook series

\begin{tabular}{|c|c|c|c|}
\hline & Primary & Lower Secondary & Upper Secondary \\
\hline Number of unit & 20 & 12 & 10 \\
\hline $\begin{array}{l}\text { Number of components per } \\
\text { unit }\end{array}$ & 3 & 7 & 8 \\
\hline \multirow[t]{9}{*}{ Component heading } & Lesson 1 & Getting Started & Getting Started \\
\hline & Lesson 2 & A Closer Look 1 & Vocabulary, Pronunciation, \\
\hline & Lesson 3 & A Closer Look 2 & Grammar \\
\hline & & Communication \& Culture & Reading \\
\hline & & Skills 1 (Reading \& & Speaking \\
\hline & & Speaking) & Listening \\
\hline & & Skills 2 (Listening \& & Writing \\
\hline & & Writing) & Communication \& Culture \\
\hline & & Looking Back \& Project & Looking Back \& Project \\
\hline $\begin{array}{l}\text { Time allocated for each } \\
\text { heading }\end{array}$ & 2 periods & 1 period & 1 period \\
\hline
\end{tabular}

(Hoang Van Van, 2015: 9)

The ten-year English textbook development project started from the second half of 2010 and ended in mid-2016. The result of the project is that a complete series of the ten-year English textbooks for schools in Vietnam was produced with the total number of 54 books (including student's books, teacher's books, and workbooks) and 20 CDs. The new textbook series adheres to the goals, the principles, the objectives, and in particular, the contents suggested in MoET's three curricula. The whole textbook series consists of 140 teaching units and 40 review units. It covers the total number of 1155 periods, of which 420 periods are allocated for the primary level (from Grade 3 to Grade 5), 420 are allocated for the lower secondary level (from Grade 6 to Grade 9), and 315 are allocated for the upper secondary level (Grade 10 to Grade 12). (For a fuller description of the ten-year English textbook series for schools in Vietnam, see Hoang Van Van, 2015, 2016).

Apart from Student's books, Teacher's books and Workbooks, the textbook development project in collaboration with MoET VEPH has produced a resource package including iebooks, a test banks and other supplementary materials. This resource package is to support students and teachers to employ the textbooks more effectively so that they can learn and teach English better. (For more detail of the resource package, visit the website sachmem.vn).

\subsubsection{Pilot teaching}

MoET required that any school that wishes to join in the trialling of the three new curricula should meet MoET's standards such as standard classrooms, standard teachers, and standard students. By standard classrooms is meant those classrooms that have sufficient learning-teaching equipment and resources, and the number of students in each class will not exceed 35. By standard teachers is meant those teachers who must achieve an English qualification equivalent to CEFR Level B2 for the primary and lower secondary levels and CEFR Level $\mathrm{C} 1$ for the upper secondary level. And by standard students is meant those students who must pass the English test designed and approved by MoET. Having considered all these conditions, on October 
15, 2010, MoET issued Decision $\mathrm{N}_{0} 4674$ / QĐ-BGDĐT on the Implementation of the Pilot English Curriculum for Primary Schools in Vietnam, on September 5, 2012, MoET issued Decision $\mathrm{N}_{0}$ 3456/QĐ-BGDĐT on the Implementation of the Pilot English Curriculum for Lower Secondary Schools in Vietnam, and on September 10, 2012, MoET issued Decision $\mathrm{N}_{0} 3702 / \mathrm{Q}$-BGDĐT on the Implementation of the Pilot English Curriculum for Upper Secondary Schools in Vietnam. (For details of these Decisions, see Bộ Giáo dục và Đào tạo [MoET], 2010b, 2012c, and 2012d).

It should be noted that the trialling of the three new English language curricula involved a great number of provinces, schools, teachers and students throughout Vietnam. At the times the three Decisions were issued, 50 provinces, 267 schools, 702 classes, 497 teachers and 27,275 students took part in it, of which 20 provinces, 94 schools, 377 classes, 95 teachers and 12,866 students took part in the trialling of the primary curriculum; 30 provinces, 88 schools, 184 classes, and 9,099 students took part in the trialling of the lower secondary curriculum; and 36 provinces, 85 schools, 141 classes, 172 teachers and 5,280 students took part in the trialling of the upper secondary curriculum. Details of these are provided in Table 5. particular, the teaching of the new textbooks at all three levels of education, a key-personnel system of teacher-orientation was employed by both MoET NFL 2020 Project and MoET VEPH. Key personnel were teachers who manifest outstanding professional skills and leadership qualities and were selected to undergo intensive orientation in the new curricula and textbooks in order to be able to pass on the message as well as to give guidance to their colleagues - other teachers. They thus had the multiplier role of ensuring positive snowballing of the new curricula and textbooks. They were selected from different provinces and were given centralized intensive training. They then went back to their respective provinces where they trained their colleagues in batches at provincial level. At first, the resentment they met from the teacher-trainees outweighed and outlived the cheers and compliments. This was not surprising as the new curricula and textbooks were new to them and they were not yet acquainted with them. Further, the textbooks seemed a bit too demanding on the teachers because it required more knowledge and skills from them and they were expected to base themselves on the contents of the textbooks to work out more activities/tasks relevant to

Table 5. Number of provinces, schools, classes, teachers and students taking part in piloting the three curricula

\begin{tabular}{|c|c|c|c|c|c|}
\hline Level & Provinces & Schools & Classes & Teachers & Students \\
\hline Primary & 20 & 94 & 377 & 95 & 12,866 \\
\hline Lower secondary & 30 & 88 & 184 & 230 & 9,099 \\
\hline Upper secondary & 36 & 85 & 141 & 172 & 5,280 \\
\hline Total & $\mathbf{5 0}^{\mathbf{3}}$ & $\mathbf{2 6 7}$ & $\mathbf{7 0 2}$ & $\mathbf{4 9 7}$ & $\mathbf{2 7 , 2 7 5}$ \\
\hline
\end{tabular}

\subsubsection{Orientation of teachers}

In order to reach all the teachers involved in the trialling of the new curricula and, in

\footnotetext{
${ }^{3}$ The reason why the total number of provinces taking part in the trialling of the three curricula is 50 is that of the 50 provinces, some take part in the trialling of one curriculum; some others of two curricula, and still some others of all the three curricula.
}

the interests and capability of the students they would be teaching. But later on, as they got acquainted with the textbooks through actual teaching, their cheers and complements outweighed and outlived their resentment.

Along with the teachers' orientation courses held by MoET NFL 2020 Project 
and MoET VEPH, some foreign language tertiary institutions (e.g. VNU University of Languages and International Studies, Hanoi University, etc.) have also been offering training courses to further develop English teachers' professional skills, ICT skills and English language skills. In their training courses, teachers are introduced to the new curricula and are helped to develop new methods and techniques of exploiting the new textbooks for more effective teaching (for more detail, see Đề án Ngoại ngũ̃ Quốc gia 2020 \& Trường Đại học Ngoại ngữ [MoET NFL 2020 Project \& VNU University of Languages and International Studies], 2017).

\subsubsection{Merits and achievements}

MoET's three pilot English language curricula for schools in Vietnam are going to finish their trial phase. A summative evaluation project on the design and implementation of these curricula is currently in progress. However, prior to this project several formative evaluation projects at ministerial and institutional levels have been conducted such as Report on the Evaluation of Pilot English Language Curriculum and Textbooks for Primary Schools in Vietnam by Bộ Giáo dục và Đào tạo [MoET] (2015), The Project "Teaching and Learning Foreign Languages in the National Education System, Period of 2008-2020" - Results of the Period of 20112015 and Implementation Plan for the Period of 2016-2020 by Ban quản lý Đề án NNQG 2020 [MoET NFL 2020 Project Management Board] (2016a), Report on the Results of the Test for Grade 12 Students in the Pilot English Language Curriculum for Upper Secondary School in 2016 by Ban quản lý Đề án NNQG 2020 [MoET NFL 2020 Project Management Board] (2016b), Report on the Evaluation of the three Pilot English Language Curricula and Proposals for the Ten-year and Twelveyear English Language Programmes by Viện Khoa học Giáo dục Việt Nam [VNIES]
(2016), Report on the Teaching and Learning of Foreign Languages at Primary Level and Proposals for a Suitable Age for Children to Start Learning Foreign Languages by Vụ Giáo dục Tiểu học [MoET Department for Primary Education] (2017), Report on the Teaching and Learning of Foreign Languages at Lower and Upper Secondary Levels by Vụ Giáo dục Trung học [MoET Department for Secondary Education] (2017), and Evaluative Report on the Implementation of the Project "Teaching and Learning Foreign Languages in the National Education System, Period 2008-2020" in the Period of 2008-2016 by Ban quản lý Đề án NNQG 2020 [MoET NFL 2020 Project Management Board] (2017). These formative evaluation projects all show that MoET's three pilot English language communicational curricula for schools in Vietnam have gained many merits in terms of both design and implementation.

\subsubsection{Merits in design}

MoET's three pilot English language curricula for schools in Vietnam are designed following the communicative approach and adhere strictly to the time frame prescribed in the Prime Minister's Decision 1400/QĐ-TTg. They set clear principles of design; contain logical sequence of contents which include three systems of themes, broken down into three system of topics, three lists of specific communicative functions (communicative competences) stated in terms of four language skills of listening, speaking, reading, and writing; and three inventories of linguistic knowledge needed for teaching English as communication, assisting students to develop their communicative competences in the selected topics.

MoET's three pilot English language curricula for schools in Vietnam have clearly defined outcomes and specific objectives for each stage of learning; have demonstrated the flexibility by taking into consideration 
the needs of the students and the learning and teaching conditions of different regions across the country: any learning and teaching contexts across the country can adapt the curricula for practical use (Bộ Giáo dục, 2015; Viện Khoa học Giáo dục Việt Nam, 2016).

MoET's three pilot English language curricula for schools in Vietnam emphasize the formation and development of communication skills; shifting focus from teaching language knowledge to teaching language skills so that students can communicate in international contexts; using English to introduce Vietnam, the land and the people to foreigners (Viện Khoa học Giáo dục Việt Nam, 2016).

MoET's three pilot English language curricula for schools in Vietnam have met the practical needs of Vietnamese general education, have had many innovative points as compared to the previous English curricula, and have created a compelling appeal to students and teachers (Bộ Giáo dục \& Đào tạo, 2015).

\subsubsection{Merits in implementation}

The ten-year English textbook series has achieved the criterion of modernity in terms of content, method and design; has been developed in accordance with MoET's three pilot English language curricula for schools in Vietnam with linguistic knowledge and contents being correct and consistently linked between levels and grades; has incorporated in it cultural features of Vietnam, of major English-speaking countries and of other countries of the world; has focused on developing students' communicative skills of listening, speaking, reading and writing, and thus have aroused students' interest in learning English, helping them get better results (Bộ Giáo dục \& Đào tạo, 2015; Viện Khoa học Giáo dục Việt Nam, 2016).

Since 2010, MoET has issued a number of directives. Most of these documents are clearly articulated, helping the provincial departments of education \& training and the pilot schools to overcome the problems experienced during the implementation process. The provincial departments of education \& training also have issued timely documents to direct the implementation of the tasks and requirements from MoET and to orient and support the pilot schools in their implementation of the pilot curricula. They have also issued guidance documents on teaching and learning, testing and assessment, teacher training, facility preparation to support the pilot schools (Bộ Giáo dục \& Đào tạo, 2015; Vụ Giáo dục Trung học, 2015).

The implementation of MoET's three pilot English language curricula for schools in Vietnam has gained strong support from the society, competent authorities of different levels, provincial departments of education and training, parents and students themselves. Since 2010 the number of provinces, schools and the number of students participating in the pilot programme has increased dramatically (Vụ Giáo dục Trung học, 2015: 5; Ban Quản lý Đề án NNQG 2020, 2017).

MoET's three pilot English language curricula for schools in Vietnam have direct influence on the compilation of textbooks, paving the way for the implementation of the "one curriculum, multiple textbooks" policy; providing orientation for textbook writers to select themes, topics, communicative competences, and linguistic and intercultural knowledge suited to each grade and each level of education. The new ten-year English textbook series is communication-based, giving priority to the development of the four communicative skills of listening, speaking, reading and writing. The components of each unit of lessons in the textbook series are coherently and logically sequenced and graded. The activities are designed following the current communicative "pre-, while-, and post-" teaching procedure to help students 
communicate effectively in English (Viện Khoa học Giáo dục, 2016).

MoET's three pilot English language curricula for schools in Vietnam have positive impacts on the professional development of the teachers: they are given opportunities to attend English language enrichment courses and training courses in methods of English language teaching and testing; those teachers who have not yet met the required English proficiency qualification (CEFR Level B2 for primary and lower secondary teachers and CEFR Level $\mathrm{C} 1$ for upper secondary teachers) will be trained (or even retrained) to the required level; those teachers who have achieved the required English qualification are given further training courses in English language teaching methodology and ICT applications (Viện Khoa học Giáo dục Việt Nam, 2016).

MoET's three pilot English language curricula for schools in Vietnam have a positive impact on students. Many students are aware of the importance of English in the context of globalization and have built up positive attitudes towards English and the culture of English-speaking countries, and have shown interest and curiosity in exploring the language and its diverse culture (Bộ Giáo dục \& Đào tạo, 2015; Viện Khoa học Giáo dục Việt Nam, 2016).

MoET's three pilot English language curricula for schools in Vietnam have positive impacts on the perception and action of the Vietnamese society: the advocacy to improve English language proficiency of school students has gained strong support from parents because their children are given an opportunity to receive 10 years of English language education to be able to communicate with foreigners in English and to go to study abroad after finishing upper secondary schools. Many parents are willing to provide their children with resources such as time, books, cassettes, iPads, hand phones, computers, etc. to help them learn English better (Vụ Giáo dục Trung học, 2015; Viện Khoa học Giáo dục Việt Nam, 2016).

The implementation of MoET's three pilot English language curricula for schools in Vietnam has yielded positive outcomes. By the end of 2016, MoET Department for Secondary Education in collaboration with MoET NFL 2020 Project held an online English test to assess the English language proficiency (listening, speaking, reading, and writing) of 5,000 twelfth graders participating in the trialling of The Pilot English Curriculum for Upper Secondary Schools in Vietnam. The results showed that $78.15 \%$ of the test takers obtained from average to excellent scores, of which $28.01 \%$ achieved excellent scores (76100 points), $24.02 \%$ achieved above average scores (65-75 points), and $28.01 \%$ achieved average scores (50-64 points). (For more detail, see Ban quản lý Đề án NNQG 2020, 2016a, 2016b, 2017; Vụ Giáo dục Trung học, 2017).

\subsubsection{Problems}

Curriculum design is complex, but because it is textual, it can be adjusted and modified to suit the new learning and teaching context and to promote more effective learning. The implementation of the curriculum seems to be much more complex, because it is social, involving so many participating variables such as policy making, steering, management, physical facilities, learning, teaching, materials (textbooks), and many others. Along with their merits and achievements as pointed out above, MoET's three pilot English language communicational curricula for schools in Vietnam have revealed a number of problems.

\subsubsection{Design problems}

The first problem related to the design of MoET's three pilot English language curricula 
for schools in Vietnam is that they seem to be heavy for normal students, particularly for those students who are in rural and mountainous areas. Some of the contents of the three curricula are not quite appropriate for Vietnamese students. However, because the requirements in these curricula are thought to be legal-bound and mandatory, teachers who have spotted the inappropriate and overloaded contents do dare to not adjust them (Bộ Giáo dục \& Đào tạo, 2015; Vụ Giáo dục Trung học, 2015).

The second problem has to do with the language proficiency requirements imposed on the teachers in MoET's three pilot English language curricula for schools in Vietnam. The requirements that to be able to teach English at primary and lower secondary levels, a teacher must have a B2 certificate and to be able to teach English at upper secondary level, a teacher must have a $\mathrm{C} 1$ certificate seem to be unrealistic if not unnecessary in the present teaching context of Vietnam. This explains why although many teachers express positive attitudes towards the requirements, there are still some who express their resentment against these standards. Experience has shown that if a primary or a lower secondary teacher who has a B1 certificate or an upper secondary teacher who has a B2 certificate has a good teaching method, s/he can still teach his/her students effectively at the respective levels (cf. Bộ Giáo dục \& Đào tạo, 2015).

The third problem is that the requirement that the number of students per class not exceed 35 seems to be infeasible, especially for classes in big cities (Bộ Giáo dục \& Đào tạo, 2015: 9; Viện Khoa học Giáo dục, 2016).

\subsubsection{Implementation problems}

A number of implementation problems has also been identified in the evalucative reports; among them 9 seem prominent.

First, MoET's directives on the implementation of three pilot English curicula often do not reach the provincial departments of education \& training and the pilot schools in time; inspection and supervision of the implementation process are not conducted timely and regularly. Personel for directing and managing the implementation of the three pilot English curricula are inadequate: most of the directors and managers of the three pilot English curricula at the provincial departments of education \& training and the pilot schools are working part-time, and do not have enough experience in programme management and implementation (Ban Quản lý Đề án NNQG 2020, 2016a).

Secondly, plans for the implementation of the three pilot English curricula for each semester and each school-year of the provincial departments of education \& training and the pilot schools are often made later than scheduled (Bộ Giáo dục \& Đào tạo, 2015).

Thirdly, information and communication work is not commensurate with the nature, the nationwide proportion and scope of the implemention of the three pilot English curicula. Information about the pilot implementation of the three curricula is not disseminated in a way that can attract attention of teachers, students and society, and thus is unable to address timely the anxiety and frustration of the teachers and students and the problems arising during the teaching and learning process (Ban Quản lý Đề án NNQG 2020, 2016a).

Fourthly, remuneration policies for teachers and students participating in pilot teaching and learning have not been properly implemented. Most teachers in the three pilot English language curicula have to teach more hours than prescribed. Students in the three pilot English language curicula are taught in CLT approach (focusing on developing their listening, speaking, reading and writing skills), and they are expected to do communicative tests, but at the national 
matriculation and general certificate of secondary education English exam, they have to do the test of traditional and noncommunicative format (mainly focusing on testing their linguistic knowledge) (For details of the national matriculation and general certificate of secondary education English exam, see Hoang Van Van, 2017).

Fifthly, there is a serious shortage of English teachers. The Prime Minister's Decision 1400-TTg prescribes that English is officially taught in Vietnamese schools for ten years (from Grade 3 to Grade 12), four hours a week at the primary level, three hours a week at the lower secondary level, and three hours a week at the upper secondary level. According to Ban Quản lý Đề án NNQG (2016a), the total number of school teachers of English in Vietnam is 69,375, of which 18,228 are primary teachers, 33,315 are lower secondary, and 17,232 are upper secondary. Due to the fact that English has been taught throughout the country three hours a week at lower secondary and upper secondary levels since 2006, there are enough teachers for the new lower secondary and the upper secondary curricula. The biggest problem, however, lies in the lack of primary teachers. At present because English is taught as an optional subject at this level, some schools are teaching two hours a week, some others - three, and some others - four or even more than four hours a week, while some others do not teach English at all. It is estimated that if all primary schools throughout the country are required to teach four hours a week, 7,000-8,000 primary teachers of English will be needed (cf. Vụ Giáo dục Tiểu học, 2017). Surely this is a problem that cannot be solved overnight.

Sixthly, there is a shortage of qualified English teachers. Since 2013, the NFL 2020 Project has been organizing training courses for in-service English teachers of all three school levels to help them get the required qualification. However, according to the latest statistics, as of March 2017, of the 18,228 primary teachers of English, only $58 \%$ have got B2 certificate (Vụ Giáo dục Tiểu học, 2017); of the 33,315 lower secondary teachers, only $56 \%$ have got B2 certificate; and of the 17,232 upper secondary teachers of English, only $48 \%$ have got $\mathrm{C} 1$ certificate (Ban Quản lý Đề án NNQG 2020, 2016a). It is not an easy task to help the remaining $42 \%$ of the primary teachers, $44 \%$ of the lower secondary teachers, and $52 \%$ of the upper secondary teachers get through to the required qualification standards within one or two years. The problem seems to be compounded when it is found that it is almost impossible to recruit primary teachers of English for rural and out-of-the-way areas, while it is quite easy for qualified teachers of English in urban and affluent areas to be attracted to work in places such as private schools, international schools, private English centers and foreign business companies as these institutions often offer them a much higher pay (see Bộ Giáo dục \& Đào tạo, 2015; see also Hoang Van Van, 2010).

Seventhly, there is a big mismatch between teaching and testing. It is ironical that while the three pilot English language curricula require that teaching should follow the communicative approach, the current testing practice in schools in Vietnam is, for the most part, non-communicative, with tests/ exams being designed in traditional/structural formats to test students' linguistic knowledge rather than their communicative skills (for more detail on this point, see Pham Viet Ha, 2016; Hoang Van Van, 2017). This big mismatch between teaching and testing is sure to hinder the success of the implementation of the new English curricula.

Eighthly, although English is recognized as one of the very few important subjects in school curriculum in Vietnam, it is not 
an entrance examination to all colleges and universities. In addition, many school students think that they can start learning English after leaving school when needed, but they cannot do the same thing with content subjects such as Maths, Physics, and Chemistry. For this reason, students often pay more attention to learning these subjects in schools.

Ninthly and finally, although English is the Number 1 foreign language being taught in Vietnam and the number of students learning English in schools accounts for 99\% (Ban quản lý Đề án NNQG 2020, 2017), it is not the language of communication in the country. For this reason, students do not have what I would refer to as "quality communication environments in English" and, as a result, they do not have the need to communicate in the language. It should be noted that although officially all lower secondary school children start learning English from Grade 6, it would be misleading to suggest that they all can speak English. In some schools, students come from situations where they are motivated to speak English, but in the majority of others they come from situations where English is not needed at all unless they are required to say a few single words in the language in the classrooms. Further, most of school pupils in Vietnam are monolingual, speaking mainly Vietnamese in almost all situations. While English is learnt in school, for quite narrow domains, and for speaking only with very few people, its use in other situations, especially in rural and mountainous areas, would be strained and unnatural, in effect, artificial. How then can one communicate in a code which one is incompetent and does not normally use for practically any situation outside the classroom? Even in urban centers, how is one to speak of communication and to stimulate a desire to communicate in English when there is precious little use for English in his/her environment?

\section{Conclusion}

\subsection{Summary}

In this paper, I have discussed in some detail the rationale, the design and the implementation of MoET's three pilot English language communicational curricula for schools in Vietnam. I have pointed out that there are good and compelling reasons scientific, political, and practical - for schools in Vietnam to change to a new English language curriculum. I have also pointed out that the design of MoET's three English language curricula for schools in Vietnam is based on two well-established theoretical foundations which have been most widely used in designing communicative foreign language curricula and syllabuses in many countries around the world: the CEFR framework and the Threshold Level English framework. In examining these important frameworks, I have tried to establish their points of relevance to the design of MoET's three English language communicational curricula and the compilation of the new ten-year English textbook series for schools in Vietnam. The discussion of the design of MoET's three pilot English language communicational curricula has proved that these curricula are up-to-date and communication-based and are, for the most part, suitable to the English language teaching and learning context of Vietnamese schools at present and in the years to come. The presentation of MoET's 10-year English textbook series has demonstrated that this is a new textbook series, compiled in accordance with the goals, the objectives and the standards set forth in MoET's threepilotEnglish language communicational curricula. The presentation of the formative evaluation reports by MoET and other institutions has shown that MoET's three pilot English language communicational curricula have gained many merits in terms of design and many achievements in terms of implementation. However, there still remain 
problems that need to be addressed before they can be officially issued and put into use in all schools throughout Vietnam.

\subsection{Recommendations}

MoET's three pilot English language communicational curricula for schools in Vietnam are in essence the most important sub-project of the Vietnamese Government's Project, “Teaching and Learning Foreign Languages in the National Education System, Period 20082020". Due to its nationwide proportion and scope, this sub-project will surely not stop at the pilot stage. To date, The Pilot English Curriculum for Primary Schools in Vietnam has been trialled for nearly seven years, The Pilot English Curriculum for Lower Secondary Schools in Vietnam and The Pilot English Curriculum for Upper Secondary Schools in Vietnam have been trialled for nearly 5 years. It is therefore high time MoET officially promulgated these three important documents and put them for use on a large scale throughout Vietnam. However, to help MoET to do these things, a more comprehensive research project should be conducted to evaluate the strengths and drawbacks of the three curricula both in terms of design and their pilot implementation. ${ }^{(4)}$

For MoET's three pilot English language curricula to be put into use on a large scale throughout Vietnam, all the problems discussed in Section 3.3.5 should be solved, but the following are immediate:

1. Some of the contents of MoET's three pilot English language curricula and of the 10-year English textbook series should be improved to meet the requirements of international integration and the realities of English language learning and teaching

\footnotetext{
${ }^{4}$ This project is being carried out by a team of both local and international curriculum experts at MoET NFL 2020 Project Management Board.
}

in Vietnamese schools.

2. MoET's three pilot English language curricula for schools in Vietnam should be combined into one single curriculum, and to attract the engagement of overseas educational publishers in producing suitable English textbooks for schools in Vietnam, the document should be issued in both Vietnamese and English.

3. The remaining $42 \%$ of the primary English teachers, $44 \%$ of the lower secondary English teachers, and 52\% of the upper secondary English teachers should be trained and retrained (if need be) for the required qualification standards so that they can function their role effectively in the new ten-year English language education programme.

4. English should be made a compulsory subject in the primary school from Grade 3 to Grade 5, and 7,000 to 8,000 primary teachers of English should be recruited to ensure that all primary students of these grades across the country receive 4 periods of English per week.

The trial phase of MoET's three pilot English language communicational curricula for schools in Vietnam is in essence a stepping stone preparing for them to be put for use on a large scale throughout Vietnam. This phase has revealed a number of problems that need to be solved. But it does not mean that we will stop, but instead we must move forward. After the pilot phase is completed and the three pilot curricula being combined into one single English language curriculum, the new ten-year English language curriculum for schools in Vietnam will be promulgated and put for use nationally. Every year, more than 15 million school pupils and approximately 80,000 teachers of English will use and benefit from this English language programme. So we should not play safe; we should not wait until all 80,000 teachers of English, all schools and classrooms across the country have reached the required standards. 
Nevertheless, in order for the new English programme to be successful, the stages that follow the pilot phase should be carefully and frugally planned, and perhaps a "slowly but surely" policy should be exercised. It is hoped that despite the problems experienced in the trial stage and those that lie ahead, with the determination of the Government and the strong support from the society, teachers, students and parents, the new ten-year English language communicational curriculum for schools in Vietnam will achieve its final goal.

\section{References}

\section{Vietnamese}

Ban Quản lý Đề án NNQG 2020 [MoET 2020 Project Management Board] (2016a). Đề án "Dạy và học ngoại ngữ trong hệ thống giáo dục quốc dân giai đoạn 2008-2020" - Kết quả giai đoạn 20112015 và kế hoạch triển khai giai đoạn 2016-2020 (The Project "Teaching and Learning Foreign Languages in the National Education System, Period of 2008-2020" - Results of the Period of 2011-2015 and Implementation Plan for the Period of 2016-2020). (Trong) Hội thảo định huóng chiến luợc phát triển dạy và học ngoại ngũ trong hệ thống giáo dục quốc dân giai đoạn 20162020. Hà Nội, tháng 6 năm 2016.

Ban quản lý Đề án NNQG 2020 [MoET 2020 Project Management Board] (2016b). Báo cáo kết quả kỳ thi đánh giá năng lưc hoc sinh lớp 12 học Chuoong trình môn tiếng Anh thi điểm cấp THPT năm 2016 (Report on the Results of the Test for Grade 12 Students in the Pilot English Language Curriculum for Upper Secondary School in 2016). (Unpublished)

Ban quản lý Đề án NNQG [MoET 2020 Project Management Board] (2017). Báo cáo tổng kêt đánh giá Đề án "Dạy và học ngoại ngũ trong hệ thống giáo dục quốc dân giai đoạn 2008-2016" (Evaluative Report on the Implementation of the Project "Teaching and Learning Foreign Languages in the National Education System, Period 20082020" in the Period of 2008-2016). (Unpublished)

Bộ Giáo dục và Đào tạo [MoET] (2015). Báo cáo đánh giá việc thi điểm chuong trình tiếng Anh tiểu hoc và sách giáo khoa tiếng Anh 3, 4, 5 (Report on the Evaluation of the Pilot English Language Curriculum and Textbooks for Primary Schools in Vietnam). Hà Nội, 2014.
Bộ Giáo dục và Đào tạo [MOET] (2010a). Chuơng trình tiếng Anh thi điểm tiểu học (Pilot English Curriculum for Primary Schools in Vietnam). (Ban hành theo Quyết định Số: 3321/QĐ-BGDĐT ngày 12 tháng 8 năm 2010 của Bộ trưởng Bộ Giáo dục và Đào tạo).

Bộ Giáo dục và Đào tạo [MoET] (2010b). Quyết định về việc triển khai Chưong trình thi điểm tiếng Anh tiểu hoc (Decision on the Implementation of the Pilot English Curriculum for Primary Schools in Vietnam). Quyết định Số 4674 /QĐ-BGDĐT.

Bộ Giáo dục và Đào tạo [MOET] (2012a). Chuơng trình giáo dục phổ thông môn tiếng Anh thi điểm cấp trung hoc co sở (Pilot English Curriculum for Lower Secondary Schools in Vietnam). (Ban hành theo Quyết định Số: 01/QĐ-BGDĐT ngày 03 tháng 01 năm 2012 của Bộ trưởng Bộ Giáo dục và Đào tạo).

Bộ Giáo dục và Đào tạo [MOET] (2012b). Chuơng trình giáo dục phổ thông môn tiếng Anh thi điểm cấp trung hoc phổ thông (Pilot English Curriculum for Upper Secondary Schools in Vietnam). (Ban hành theo Quyết định Số: 5290/QĐ-BGDĐT ngày 23 tháng 11 năm 2012 của Bộ trưởng Bộ Giáo dục và Đào tạo).

Bộ Giáo dục và Đào tạo [MoET] (2012c). Quyết định về việc triển khai Chuoong trình giáo duc phổ thông môn tiếng Anh thi điểm cấp trung hoc co sỏ (Decision on the Implementation of the Pilot English Curriculum for Lower Secondary Schools in Vietnam). Quyết định Số 3456/QĐ-BGDĐT.

Bộ Giáo dục và Đào tạo [MoET] (2012d). Quyết định về viẹc triển khai Chuoong trình giáo dục phố thông môn tiếng Anh thi điểm cấp trung hoc phổ thông (Decision on the Implementation of the Pilot English Curriculum for Upper Secondary Schools in Vietnam). Quyết định Số 3702/QĐ-BGDĐT.

Đề án Ngoại ngữ Quốc gia 2020 \&Trường Đại học Ngoại ngữ [MoET NFL 2020 Project \& VNU University of Languages and International Studies] (2017). $K y$ yếu hội nghị cấp quốc gia giới thiệu bộ tài liệu bồi duõng giáo viên sủ dụng sách giáo khoa tiếng Anh mới theo mô hình bồi dương giáo viên mói (kết hợp trục tiếp và trục tuyến). Hà Nội tháng 8 năm 2017.

Phạm Việt Hà (2016). Bài thi trung học phổ thông quốc gia môn tiếng Anh năm 2015: Phân tích trên cơ sở các tài liệu công khai (The 2015 National Matriculation and General Certificate of Secondary Education English Test: An Analysis Based on Public Data). (Trong) Kỷ yếu hội thảo quốc gia: Đổi mói phương pháp giảng dạy và kiểm tra, đánh giá giáo dục ngoại $n g u \tilde{u}$. Hà Nội: Nxb. Đại học Quốc gia Hà Nội. 
Thủ tướng Chính phủ [The Prime Minister of the SRV] (2008). Đề án "Dạy và họ ngoại ngũ trong hệ thống giáo dục quốc dân giai đoạn 2008-2020" (Teaching and Learning Foreign Languages in the National Education System, Period 2008-2020). (Ban hành theo Quyết định số 1400/QĐ-TTg ngày 30 tháng 9 năm 2008).

Hoang Van Van (2017). Bài thi trung học phổ thông quốc gia và xét tuyển vào đại học, cao đẳng môn tiếng Anh năm 2016: Một thách thức đối với mục tiêu giáo dục ngoại ngữ ở trường phổ thông Việt Nam (The 2016 National Matriculation and General Certificate of Secondary Education English Test: A Challenge to the Goal of Foreign Language Education in Vietnamese Schools). Nghiên cúu Nước ngoài, 33(2), 1-20.

Viện khoa học Giáo dục Việt Nam (2008). Đề án dạy và học ngoại ngũ trong hệ thống giáo dục quốc dân giai doạn 2008-2020 (Teaching and Learning Foreign Languages in the National Education System, Period 2008-2020). (Unpublished). Hà Nội-2008.

Viện Khoa học Giáo dục Việt Nam [VNIES] (2016). Đánh giá chuoong trình tiếng Anh thi điểm, đề xuất về chuoong trình tiếng Anh hệ 10 năm và 12 năm (Report on the Evaluation of the three Pilot English Language Curricula and Proposals for the Ten-year and Twelve-year English Language Programmes). (Unpublished).

Vụ Giáo dục tiểu học [MoET Department for Primary Education] (2017). Báo cáo về việc dạy và học ngoại ngữ cấp tiểu học và đề xuất độ tuổi/lớp học nên bắt đầu dạy môn ngoại ngữ (Report on the Teaching and Learning of Foreign Languages at Primary Level and Proposals for a Suitable Age for Children to Start Learning a Foreign Language). (Trong) Ky yếu Hội thảo khoa học về môn học ngoại ngũ trong chuoong trình giáo dục phổ thông tổng thể. Hà Nội, tháng 3 năm 2017.

Vụ Giáo dục Trung học [MoET Department for Secondary Education] (2015). Báo cáo tình hình triển khai dạy học môn tiếng Anh cấp trung học theo Đề án Ngoại ngũ Quốc gia 2020 năm học 20142015. (Unpublished).

Vụ Giáo dục Trung học [MoET Department for Secondary Education] (2017). Báo cáo về việc dạy và học ngoại ngữ - cấp trung học (Report on the Teaching and Learning of Foreign Languages at Lower and Upper Secondary Levels). (Trong) $K \dot{y}$ yếu Hội thảo khoa học về môn học ngoại ngũ trong chuoong trình giáo duc phổ thông tổng thể. Hà Nội, tháng 3 năm 2017.

\section{English}

Breen, M. P., \& C. N. Candlin (1980). The Essentials of a Communicative Curriculum in Language Teaching. Applied Linguistics, 1(2), 89-112.

Broek, S. I. van den Ende, (2013). The Implementation of the Common European Framework for Language in European Education Systems. European Parliament: EN DE FR.

Broughton, G., C. Brumfit, R. Flawell, P. Hill, \& A. Pincas (1978). Teaching English as a Foreign Language. London, Henley and Boston: Routledge \& Kegan Paul.

Bučar, C. S. et al (2014). The CEFR and Teaching Japanese as a Foreign Language. Retrieved from https://www.google.com.vn/search?q=THE+ CEFR+AND+TEACHING+JAPANESE+AS $+\mathrm{A}+\mathrm{FOREIGN}+\mathrm{LANGUAGE \& rlz}=1 \mathrm{C} 1 \mathrm{CH}$ BF enVN707VN707\&oq $=\mathrm{THE}+\mathrm{CEFR}+\mathrm{AND}$ + TEACHING+JAPANESE+AS+A+FOREIG N+LANGUAGE\&aqs $=$ chrome..69i57.3723j0j 8\&sourceid $=$ chrome\&ie $=\mathrm{UTF}-8$

Chamot, A. U. (1987). Towards a Functional ESL Curriculum in the Elementary School. (In) Methodology in TESOL: A Book of Readings. Massachusetts: Heinle \& Heinle.

Chan, W. M., K. N. Chin \& T. Suthiwan (Eds.) (2011). Foreign Language Teaching in Asia and Beyond: Current Perspectives and Future Directions. Germany: De Gruyter Mouton.

Council of Europe (2001). Common European Framework of Reference for Languages: Learning, Teaching, Assessment. Cambridge: Cambridge University Press. Available at http://www.coe.int/t/ dg4/education/elp/elpreg/Source/Key_reference/ CEFR_EN.pdf. Retrieved 8 Nov 2017.

Darus, S. (2010). The Current Situation and the Teaching of English in Malaysia. Ritsumeikan Studies of Language and Culture, 22, 19-27. Retrieved from $\quad w w w . a c a d e m i a . e d u / . . / T h e$ current situation and issues of the teach...

Eurydice (2005). Key Data on Teaching Languages at School in Europe. 2005 edition. Brussels: Eurydice.

Finch, A. (2009). Europass and the CEFR: Implications for Language Teaching in Korea. Retrieved from http:/www.finchpark.com/arts/ Europass 2009.pdf.

Halliday, M. A. K. (1973). Explorations in the Functions of Language. London: Edward Arnold.

Halliday M. A. K. (1978). Language as Social Semiotic: The Social Interpretation of Language and Meaning. 
London: Arnold.

Halliday, M. A. K. (1991). The Notion of Context in Language Education. (In) Thao Le \& McCausland (Eds.), Language Education: Interaction and Development (pp. 1-25). Proceedings of the International Conference Held in Ho Chi Minh City, 30 March - 1 April, 1991. Launceston: University of Tasmania.

Halliday, M. A. K. (1998). Towards a Sociological Semantics. (In) Brumfit, C. F. \& K. Johnson (Eds.), The Communicative Approach to Language Teaching (pp.27-45). Oxford: Oxford University Press.

Hoang Van Van (2010). The Current Situation and Issues of the Teaching of English in Vietnam. Ritsumeikan Studies in Language and Culture, 22(1), 7-18.

Hoang Van Van (2015). The Development of the Tenyear English Textbook Series for Vietnamese Schools under the National Foreign Languages 2020 Project: A Cross-cultural Collaborative Experience. VNU Journal of Science - Foreign Studies, 31(3), 1-17.

Hoang Van Van (2016). Renovation in Curriculum Design and Textbook Development: An Effective Solution to Improving the Quality of English Teaching in Vietnamese Schools in the Context of Integration and Globalization. VNU Journal of Science: Education Research,32(4), 9-20.

Hymes, D. H. (1972). On Communicative Competence. (In) Pride, J. B. \& J. Holmes (Eds.), Sociolinguistics. Baltimore: Penguin Books.

Kwon, O. (2010). The Current Situation and the Teaching of English in Korea. Ritsumeikan Studies of Language and Culture, 21, 21-34. Retrieved from www.ritsumei.ac.jp/acd/re/k.../ RitsIILCS 21.2pp21-34KWON.pdf

Lam, A. S. L. (2005). Language Education in China. Policy and Experience from 1949. Hong Kong: Hong Kong University Press.

Lee, I. (2005). English Language Teaching in Hong Kong Special Administrative Region (HKSAR): A Continuous Challenge. (In) Teaching English to the World: History, Curriculum, and Practice (pp. 35-46). London: Lawrence Erlbaum Associates, Publishers.

Lenneberg, E. H. (1967). Biological Foundations of Language. New York: Wiley.

Lightbown, P. M. \& N. Spada (2008). How Languages are Learned. Oxford: Oxford University Press.

Liu, J. (2010). The Current Situation and the Teaching of English in China. Ritsumeikan Studies of Language and Culture, 21,21-34. Retrieved Oct. 12, 2016 from www.ritsumei.ac.jp/acd/re/k.../RitsIILCS 21.2pp713JONGUIN.pdf

Long, M. H. \& J. C. Richards (Eds.). Methodology in TESOL: A Book of Readings. Boston: Heinle \& Heinle.

Nikolov, M. (Ed.) (2009). Early Learning of Modern Foreign Languages: Processes and Outcomes. Bistol, Buffalo, Toronto: Multilingual Matters.

Pew Research Center (2015). Learning a Foreign Language a 'Must' in Europe, not so in America. Retrieved from http://www.pewresearch.org/facttank/2015/07/13/learning-a-foreign-language-amust-in-europe-not-so-in-america/

Rivers, W. M. (1970). Teaching Foreign-Language Skills. Chicago and London: The University of Chicago Press.

Rubdy, R. and T. R. F. Tupas (2009). Research in Applied Linguistics and Language Teaching and Learning in Singapore (2000-2007). Language Teaching, 42(3), 317-340.

Stern, H. H. (1967). Foreign Languages in Primary Education: The Teaching of Second or Foreign Languages to Young Children. Oxford: Oxford University Press.

Strevens, P. (1985). New Orientations in the Teaching of English. Oxford: Oxford University Press.

van Ek, J. A. \& L. G. Alexander. (1975/1980). Threshold Level English. Council of Europe: Pergamon Press.

van Ek, J. A. (1977). The Threshold Level for Modern Language Learning in Schools. London: Longman.

van Ek, J. A. (1998). The Threshold Level. (In) Brumfit, C. J. \& K. Johnson (Eds.). The Communicative Approach to Language Teaching (pp. 103-116). Oxford: Oxford University Press. 


\title{
BA CHƯƠNG TRÌNH TIẾNG ANH GIAO TIẾP THÍ ĐIỂM DÀNH CHO CÁC TRƯỜnG PHỔ THÔNG Ở VIẸTT NAM CỦA BỘ GIÁO DỤC VÀ ĐÀO TẠO: CĂN CỬ THIẾT KẾ, CÁCH THIẾT KẾ VÀ TRIỂN KHAI THỤ̉C HIỆN
}

\author{
Hoàng Văn Vân \\ Trung tâm Nghiên cưu Giáo dục Ngoại ngũ, Ngôn ngũ và Quốc tế học, \\ Truò̀ng Đại học Ngoại ngũu, ĐHQGHN, Phạm Văn Đồng, Cầu Giấy, Hà Nội, Việt Nam
}

Tóm tắt: Trong bài viết này, chúng tôi sẽ thảo luận ba chương trình tiếng Anh giao tiếp thí điểm dành cho các trường phổ thông ở Việt Nam của Bộ Giáo dục và Đào tạo. Để làm việc này, chúng tôi sẽ tổ chức bài viết thành bốn phần chính. Phần 1 nêu lí do chọn đề tài. Phần 2 trình bày các căn cứ để phát triển ba chương trình tiếng Anh giao tiếp thí điểm dành cho các trường phổ thông ở Việt Nam của Bộ Giáo dục và đào tạo. Phần 3 là trọng tâm của bài báo. Trong phần này, trước hết chúng tôi sẽ trình bày tổng quát nội dung của Khung Tham chiếu chung châu Âu đối với Ngôn ngũ: Học tập, Giảng dạy, Đánh giá (CEFR) và Tiếng Anh bậc cơ sở (Threshold Level English) - hai công trình nghiên cứu quan trọng đặt nền tảng lí luận cho việc phát triển ba chương trình tiếng Anh thí điểm dành cho các trường phổ thông ở Việt Nam của Bộ Giáo dục và Đào tạo. Sau đó, chúng tôi sẽ mô tả chi tiết cách thiết kế của ba chương trình tiếng Anh thí điểm dành cho các trường phổ thông ở Việt Nam của Bộ Giáo dục và Đào tạo và thảo luận về quá trình triển khai thực hiện dạy và học thí điểm ba chương trình này, nêu bật những thành tựu đạt được và những vấn đề gặp phải trong quá trình triển khai thực hiện thí điểm. Trong phần cuối cùng, sau khi tóm tắt lại những nội dung đã thảo luận, chúng tôi sẽ khuyến nghị tích hợp ba chương trình tiếng Anh giao tiếp thí điểm thành một chương trình thống nhất có thể được gọi là Chuơng trình giáo dục phổ thông môn tiếng Anh và đề xuất một số kiến nghị về những việc nên làm để khắc phục những tồn tại trước khi đưa Chuoong trình giáo dục phổ thông môn tiếng Anh vào sử dụng trên phạm vi cả nước.

Tì khoá: chương trình tiếng Anh giao tiếp thí điểm của Bộ GD \& ĐT, khung CEFR, Tiếng Anh bậc co sở (Threshold Level English), Đề án Ngoại ngữ Quốc gia 2020 (Đề án NNQG 2020) 